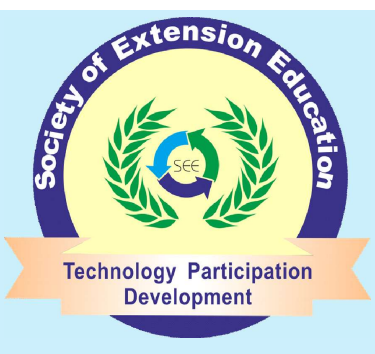

Research Note

\section{Indian Research Journal of Extension Education}

ISSN: 0972-2181 (Print), 0976-1071 (Online)

NAAS Rating : $\mathbf{5 . 2 2}$

Journal homepage: seea.org.in

https://doi.org/10.54986/irjee/2022/jan_mar/138-141

\title{
Domestic Violence Against Women in During Covid-19 Lockdown
}

\author{
Madhulika Gautam ${ }^{1}$, Neha Agarwal ${ }^{2}$ and Khushboo ${ }^{3}$ \\ 1.Asso. Prof., 2. Res. Scholar, 3. PG Student (Home Sc.), DEI (Deemed University), Dayalbagh, Agra, UP, India, \\ Corresponding author e-mail : malika1204@gmail.com
}

Paper Received on October 25, 2021, Accepted on November 28, 2021 and Published Online on January 01,2022

\begin{abstract}
The problem of violence for women has increased during the pandemic period of COVID-19. The present study was conducted to assess the status of women related to domestic violence during lockdown. This study was conducted in Badaun District and total fifty-five respondents were selected by snow ball technique. The data was collected through telephonic communication. The findings of the present study show that the status of physical, psychological, financial and sexual violence for working women was similar that of women who were housewives and this similarity was found to be insignificant $(t=1.01,0.17,0.08,0.45)$ continuously. The status of sexual violence in women of below 30 years (4.11) was not different to that of women above 30 years (4.45) and it was evident from the $t$ value (0.97) which was insignificant. This study highly recommended focusing on the situation of women and it suggests that awareness programs should be arranged by which the women would not hesitate to discuss their problems regarding the violence which they might be facing.
\end{abstract}

Key words: COVID-19; Domestic violence; Lockdown; Underprivileged women.

$\mathbf{W}_{\text {omen are facing domestic violence from ancient }}$ period. Today the violence against women is an uncontrollable phenomenon for the result of murder rape, abduction and torture. The problem of violence for women has increased during the pandemic period of COVID- 19. Lack of awareness regarding their rights and low literacy level increase the problem of domestic violence. Such type of reasons involves to become women situation more uncontrollable and worse. The nationwide lockdown has increased the cases of domestic violence where Uttarakhand has recorded the highest number of cases while Haryana is on second and Delhi is on third number (NCW, 2020). As researcher has not found any data on this vital aspect in Uttar Pradesh. This study can be thrown light on Badaun district and it will also help to know about the consequences of domestic violence. So present study was conducted on Badaun district of Uttar Pradesh entitled 'To assess the status of women related to domestic violence during lockdown' with objectives of to assess the awareness and status of domestic violence against women.

\section{METHODOLOGY}

The study was conducted in Badaun district and snow ball technique was used to select the sample. Total fifty-five married women were selected for the study. Only aware women regarding domestic violence were selected for the present study. The data was collected through telephonic communication. Self-prepared interview schedule was used to collect data. It consists four major domains of domestic violence which are physical, psychological, financial, sexual 


\section{RESULTS AND DISCUSSIONS}

Physical Violence: The Table 1 shows the status of physical violence against women during lockdown. The researcher found that most of the women $(70.00 \%)$ were faced physical violence by their husband. Similarly between 2011 and 2018 in 11 countries included India analysed that most of women faced physical violence by their husband (Kalai et al., 2018) and (Jeong et al., 2020). Followed by mother-in-law (32.00\%) and least of the women $(10.00 \%)$ were faced that violence by other family members.

The most of women $(74.00 \%)$ experienced violence by slapping, 51.00 per cent beating, 43.00 per cent hitting, 40.00 per centkicking. It affected women harmfully and total 68.00 per cent of them were not able to perform activities, 58.00 per cent of them could not work properly whereas 50.00 per cent of them were not able to sit

Table 1. Physical violence against women during lockdown

\begin{tabular}{|c|c|c|c|c|c|c|}
\hline \multicolumn{5}{|c|}{ Forms of violence } & No. & $\%$ \\
\hline \multicolumn{7}{|c|}{ Offender of physical violence } \\
\hline \multicolumn{4}{|l|}{ Husband } & \multicolumn{2}{|r|}{38} & 70.00 \\
\hline \multicolumn{4}{|c|}{ Mother in law } & \multicolumn{2}{|r|}{16} & 32.00 \\
\hline \multicolumn{4}{|l|}{ Sister in law } & \multicolumn{2}{|r|}{11} & 21.00 \\
\hline \multicolumn{5}{|c|}{ Others (Father in law, Brother in law etc.) } & 5 & 10.00 \\
\hline \multicolumn{7}{|c|}{ Experienced various forms of physical violence } \\
\hline \multicolumn{4}{|l|}{ Hitting } & \multicolumn{2}{|c|}{23} & 43.00 \\
\hline \multicolumn{4}{|l|}{ Kicking } & \multicolumn{2}{|r|}{25} & 40.00 \\
\hline \multicolumn{4}{|l|}{ Beating } & \multicolumn{2}{|r|}{27} & 51.00 \\
\hline \multicolumn{4}{|l|}{ Slapping } & \multicolumn{2}{|c|}{40} & 74.00 \\
\hline \multicolumn{7}{|c|}{ Harmful effects of physical violence on women } \\
\hline \multicolumn{4}{|c|}{ Can't sit properly } & \multicolumn{2}{|c|}{27} & 50.00 \\
\hline \multicolumn{4}{|c|}{ Can't walk properly } & \multicolumn{2}{|c|}{31} & 58.00 \\
\hline \multicolumn{4}{|c|}{ Can't perform activities } & \multicolumn{2}{|c|}{38} & 68.00 \\
\hline \multicolumn{7}{|c|}{ Intensity of physical violence } \\
\hline \multicolumn{4}{|c|}{ Increased due to lockdown } & \multicolumn{2}{|c|}{40} & 70.00 \\
\hline \multicolumn{4}{|c|}{ Usual as before } & \multicolumn{2}{|c|}{15} & 30.00 \\
\hline \multicolumn{7}{|c|}{$\begin{array}{l}\text { Table 2. Status of physical violence according to } \\
\text { idependent variables of women }\end{array}$} \\
\hline Variables & Category & $\mathrm{N}$ & Mean & $\mathrm{SD}$ & $\mathrm{t}$ & $\mathrm{P}$ \\
\hline \multirow[t]{2}{*}{ Age (yrs.) } & $<30$ & 17 & 4.22 & 1.29 & 0.75 & $>0.05$ \\
\hline & $>30$ & 38 & 4.51 & 1.38 & & \\
\hline Occupation & Working & 35 & 4.00 & 1.39 & 1.01 & $>0.05$ \\
\hline & House wife & 20 & 3.64 & 1.19 & & \\
\hline Monthly & $<5000$ & 29 & 3.63 & 1.30 & 0.28 & $>0.05$ \\
\hline income (Rs.) & $>5000$ & 26 & 3.54 & 1.10 & & \\
\hline Educational & $<5^{\text {th }}$ std. & 30 & 4.47 & 1.30 & 0.38 & $>0.05$ \\
\hline & $>5^{\text {th }}$ std. & 25 & 4.34 & 1.21 & & \\
\hline
\end{tabular}

properly. Most of the women (70.00\%) faced intensity of physical violence increased during the lockdown. Similar results were found by Ravindran \& Shah (2020).

The Table 2 indicated the status of physical violence according to the age, occupation, family income and educational status of women. Those women who below 30 years of age the status of physical violence (4.22) was similar to that of women above 30 years of age (4.51). That was evident by the t-value (0.75) which was insignificant. However, Kalokhe et. al (2017) reported that the women with over age of 50 experienced higher risk of physical violence. The status of physical violence for working women (4.00) was like that of women who were housewives (3.64) and it was clear from the t-value (1.01) which was insignificant. The women whose family income was below Rs.5000, the status of physical violence (3.63) was similar to that of women whose family income was above Rs. 5000 (3.54) and that was evident from the t value $(0.28)$ which was insignificant. The women whose educational status was below $5^{\text {th }}$ grade status of physical violence (4.47) was similar to that of women whose educational status was above $5^{\text {th }}$ grade (4.34) and it was clear from the t-value (0.38) which was insignificant.

Table 3. Psychological violence against women during lockdown

\begin{tabular}{lll}
\hline Forms of violence & No. & $\%$ \\
\hline Experienced psychological violence & & \\
Verbal abuse & 34 & 62.00 \\
Insult & 37 & 69.00 \\
Blaming & 20 & 38.00 \\
Shaming & 28 & 52.00 \\
Harmful effects of psychological violence & & \\
Stress & 34 & 63.00 \\
Depression & 39 & 72.00 \\
Anxiety & 37 & 69.00 \\
Harming self & 31 & 58.00 \\
Intensity of psychological violence & & \\
Increased due to lockdown & 39 & 72.00 \\
Usual as before & 16 & 28.00 \\
\hline
\end{tabular}

Psychological violence: The above Table 3 shows the status of psychological violence against women during lockdown. As per the data the higher percentage of women with 69.00 per cent who experienced psychological violence through insult, verbal abuse $(62.00 \%)$, shaming $(52.00 \%)$ and the less percentage of women with 38.00 per cent through blaming. Most of the women $(72.00 \%)$ were affected by depression 
followed by anxiety $(69.00 \%)$, stress $(63.00 \%)$ and harming self $(58.00 \%)$. The data also revealed the intensity of psychological violence had increased by 72.00 per cent due to lockdown Ravindran \& Shah, 2020 also reported similar results.

Table 4. Status of Psychological violence according to the idependent variables of women

\begin{tabular}{lllllll}
\hline Variables & Category & $\mathrm{N}$ & Mean & $\mathrm{SD}$ & $\mathrm{t}$ & $\mathrm{P}$ \\
\hline Age (yrs.) & $<30$ & 21 & 1.96 & 0.95 & 0.18 & $>0.05$ \\
& $>30$ & 34 & 2.01 & 1.02 & & \\
Occupation & Working & 32 & 2.54 & 1.18 & 0.17 & $>0.05$ \\
& House wife & 23 & 2.49 & 1.09 & & \\
Family & $<5000$ & 28 & 2.19 & 1.08 & 0.14 & $>0.05$ \\
income (Rs.) & $>5000$ & 27 & 2.15 & 1.02 & & \\
Educational & $<5^{\text {th }}$ std. & 33 & 2.10 & 1.10 & 0.10 & $>0.05$ \\
status & $>5^{\text {th }}$ std. & 22 & 2.07 & 1.06 & & \\
\hline
\end{tabular}

The Table 4 reveals the status of psychological violence according to the age, occupation, family income per month and educational status of women. The status of psychological violence in women whose age was below 30 years (1.96) was similar to that of women whose age was above 30 years (2.01) and it was evident from the $t$ value $(0.18)$ which was insignificant. The status of psychological violence for working women (2.54) was similar to that of women who were housewives (2.49) and it was evident from the $t$ value $(0.17)$ which was insignificant. Women whose family income was below 5000 Rupees the status of psychological violence (2.19) was similar to that of women whose family income was above 5000 Rupees (2.15) and it was evident from the t value $(0.14)$ which was insignificant. The status of psychological violence in women whose educational level was below $5^{\text {th }}$ grade (2.10) was similar to that of women whose educational level was above $5^{\text {th }}$ grade (2.07) and it was evident from the $t$ value $(0.10)$ which was insignificant.

Table 5. Financial abuse against women during lockdown

\begin{tabular}{lll}
\hline Financial abuse & No. & $\%$ \\
\hline Experienced financial abuse & 38 & 68.00 \\
Effects of financial abuse on women & & \\
Lot of dependence & 38 & 70.00 \\
Financial instability & 33 & 61.00 \\
Concern about future plans & 30 & 56.00 \\
Intensity financial abuse & & \\
Increased due to lockdown & 39 & 72.00 \\
Usual as before & 16 & 28.00 \\
\hline
\end{tabular}

Financial abuse: The Table 5 reveals that total 68.00 per cent of women had experienced of financial abuse during lockdown. Most of the women (70.00\%) were dependent financially on others. The data also revealed that the intensity of financial abuse was increased due to lockdown by 72.00 per cent while 28.00 per cent of women said that it was usual as before.

Table 6. Status of financial abuse according to the idependent variables of women

\begin{tabular}{lllllll}
\hline Variables & Category & $\mathrm{N}$ & Mean & $\mathrm{SD}$ & $\mathrm{t}$ & $\mathrm{P}$ \\
\hline Age (yrs.) & $<30$ & 19 & 2.89 & 1.08 & 0.06 & $>0.05$ \\
& $>30$ & 36 & 2.91 & 1.11 & & \\
Occupation & Working & 33 & 2.52 & 1.51 & 0.08 & $>0.05$ \\
& House wife & 22 & 2.49 & 1.33 & & \\
Family & $<5000$ & 31 & 1.54 & 0.91 & 0.20 & $>0.05$ \\
income (Rs.) & $>5000$ & 24 & 1.49 & 0.89 & & \\
Educational & $<5^{\text {th }}$ std. & 29 & 1.92 & 0.91 & 0.25 & $>0.05$ \\
status & $>5^{\text {th }}$ std. & 26 & 1.98 & 0.89 & & \\
\hline
\end{tabular}

The Table 6 highlights the status of financial abuse in women of below 30 years (2.89) was similar to the women of above 30 years (2.91) and it was clear that the t-value (0.06) which was insignificant. The status of financial abuse for working women (2.52) was similar to the housewives (2.49) and the t-value was (0.08) which was insignificant. The status of financial abuse in women with family income of below Rs. 5000 (1.54) was similar to the women with family income of above Rs. 5000 (1.49) and also evident from the t-value (0.20) which was insignificant. The status of financial abuse in women with education of below $5^{\text {th }}$ std. (1.92) was similar to the women with education of above $5^{\text {th }}$ std. (1.89) and that was also insignificant (t-value, 0.25 ).

Table 7. Status of sexual violence against women

\begin{tabular}{lll}
\hline Forms & No. & $\%$ \\
\hline Experienced sexual violence & 42 & 78.00 \\
Harmful effects of sexual violence on women & & \\
Infertility & 28 & 52.00 \\
Sexually Transmitted Infections & 11 & 20.00 \\
Unwanted pregnancy & 38 & 68.00 \\
Effects on mental health & & \\
Depression & 38 & 68.00 \\
Stress & 42 & 78.00 \\
Substance abuse & 34 & 62.00 \\
Intensity of sexual violence & & \\
Increased due to lockdown & 42 & 75.00 \\
Usual as before & 13 & 25.00 \\
\hline
\end{tabular}

Sexual Violence: The Table 7 shows that total 78.00 per cent of women had experienced sexual violence during lockdown and the majority of women $(68.00 \%)$ 
had faced unwanted pregnancy as the harmful effects of sexual violence followed by infertility, STI (Sexually Transmitted Infections) etc. Jeong et al. (2020) and Saikia, 2020) also reported that most of women experienced sexual violence under IPV (Intimate Partner Violence). The mental health was affected because of sexual violence and most of the women $(78.00 \%)$ had faced the problem of stress, depression and substance abuse etc. The intensity of violence has increased due to lockdown $(75.00 \%)$ while 25.00 per cent of women experienced usual as before lockdown. Ravindran \& Shah, 2020 also found similarity in results.

Table 8. Status of sexual violence according to idependent variables of women

\begin{tabular}{lllllll}
\hline Variables & Category & $\mathrm{N}$ & Mean & $\mathrm{SD}$ & $\mathrm{t}$ & $\mathrm{P}$ \\
\hline Age in (yrs.) & $<30$ & 21 & 4.11 & 1.18 & 0.97 & $>0.05$ \\
& $>30$ & 34 & 4.45 & 1.38 & & \\
Occupation & Working & 36 & 4.00 & 1.39 & 0.45 & $>0.05$ \\
& House wife & 19 & 3.84 & 1.19 & & \\
Family & $<5000$ & 29 & 4.10 & 1.30 & 0.65 & $>0.05$ \\
income (Rs.) & $>5000$ & 26 & 3.89 & 1.10 & & \\
Educational & $<5^{\text {th }}$ std. & 30 & 4.12 & 1.30 & 0.89 & $>0.05$ \\
status & $>5^{\text {th }}$ std. & 25 & 3.82 & 1.21 & & \\
\hline
\end{tabular}

Table 8 highlights the status of sexual violence in women of below 30 years (4.11) was similar to that of women above 30 years (4.45) and it was evident from the t-value (0.97) which was insignificant. The status of sexual violence for working women (4.00) was similar to that of housewives (3.84) and the t-value (0.45) which was insignificant. The status of sexual violence in women with family income of below Rs. 5000 (4.10) was similar to the women with family income of above Rs. 5000 (3.89) and it was clear from the t-value (0.65) which was insignificant. The status of sexual violence in women with below $5^{\text {th }}$ grade (4.12) was similar to that of women with above $5^{\text {th }}$ grade (3.82) and it was depicted from the t-value (0.89) which was insignificant.

Implications of the study: The present study highlights the poor condition of women because of domestic violence and it tells about the need for the improvement of women's condition and to aware them about what is domestic violence.

\section{CONCLUSION}

It is analysed that both housewives and working women have stayed at home for longer duration due to the era of COVID-19 lockdown and the results indicate that the intensity of domestic violence was higher as compared to usual days among working women and housewives. There was no difference seen in domestic violence among women according to their age, working status, family income and educational status. These factors are needed to be more focused to reduce the problem of domestic violence.

\section{CONFLICTS OF INTEREST}

The authors declare that they have no conflicts of interest.

\section{REFERENCES}

Jeong, J.; Adhia, A.; Bhatia, A.; McCoy, D. C. and Yousafzai, A. K. (2020). Intimate partner violence, maternal and paternal parenting, and early child development. Americal academy of pediatrics. 145 (6) e20192955; DOI: https://doi.org/10.1542/ peds.2019-2955

Kalai, K. and Devarani, L. (2018). Gender differences in agricultural empowerment: a cross-cultural study in Tripura. Indian Res. J. Ext.Edu., 18 (3) : 76-82. Retrieved July, 2018 From https://www.seea.org.in

Kalokhe, A.; Rio, C. D.; Dunkle, K.; Stephenson R.; Methenyd, N.; Paranjapee, A. and Sahay, S. (2017). Domestic violence against women in India: A systematic review of a decade of quantitative studies. Glob Public Health. 12(4): 498-513.

National Commission for Women (NCW), (2020, April). Rashtra Mahila. Vol 1, No. 244. Retrieved Jan.15, 2021 from http:// ncw.nic.in

Ravindran, S. and Shah, M. (2020). Unintended consequences of lockdowns: COVID-19 and the shadow pandemic. NBER working paper. No. 27562 July 2020, Revised in September 2020 JEL No. I15, I18, J12, J16, O15

Saikia, Pubali (2020). Awareness of legal rights among rural women entrepreneurs in north east region of India. Indian Res. J. Ext.Edu., 20 (2\&3):119-122. Retrieved July, 2018 From https://www.seea.org.in 